Mane KHACHIBABYAN

UDC 1/14:93/94

\title{
“THE UNEXAMINED LIFE IS NOT WORTH LIVING": THE ARMENIAN GENOCIDE
}

\begin{abstract}
The article discusses the work, research and efforts Professor Armen Marsoobian has done towards explicating and representing the fragments left from the Armenian Genocide period. Armenian Genocide has had its huge impact on the lives of Armenian people and the national ideology.

Professor Marsoobian, through photography exhibitions and his books, retells the story of Armenian people and events of 1915 to the world. The past needs to be examined, for we need to clearly understand the reasoning behind historical events, in order to prevent and be more secure in future.
\end{abstract}

Key words: Armenian genocide, history, 1915, photography, family, ancestors, massacre.

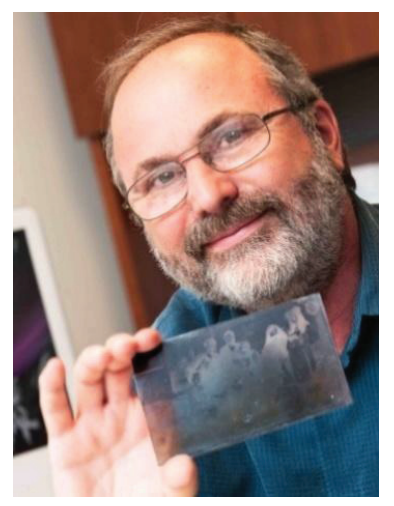

The statement by Socrates "Unexamined life is not worth living" applies to every aspect of our lives.

Philosophers raise questions and explore vital topics that need to be examined, highlighted and explained. What about Armenian philosophers? Every Armenian throughout his or her life is connected to our history, history that is full of pain and struggle. Armenian Genocide and the fight for achieving recognition are forever sealed in the national identity of Armenians.

Dr. Armen T. Marsoobian is an ArmenianAmerican professor, who has been realizing a project that aims to bring Turks and Armenians closer through sharing the common past, as well as estab- lish new standpoints to the long existing issue. The overall objective of the project is the memorialization of the Armenian Genocide in Turkey. It consists of two books, photography exhibitions and foundation of memorial sites that are linked with the Dildilians' (his mother's family), which all together come to tell us about the pre, after and post genocide times in Ottoman Turkey. The project also includes various lecture series in different parts of the world, all of which are in the frames of the Armenian Studies Program.

Armenian Genocide, Holocaust and other genocides are depicted in thousands of photos that were preserved over time. The history of Armenian Genocide is acknowledged through thousands of 
documents, memoirs, reports, eyewitness testimonies and stories of survivors. Photos by foreign and Armenian photographers during the years of Genocide come to serve as exceptional proofs of the history that is still being denied. Marsoobian's photography exhibitions are new sources of information and proofs. The exhibitions initially launched in Istanbul, Merzifon, Ankara and Diyarbakır featuring photographs that document the social life of the Armenian people living in Anatolia, throughout the 19th century. Marsoobian's ancestors, the Dildilian family practised photography, and the photographs presented in the exhibitions were given to him by his uncle towards the end of his life. Hundred photos were chosen to be presented out of thousands.
Each and every photo carries a great responsibility to transfer unique and important information about Armenian Genocide or Armenian social life of those times. These photo-stories convey messages and history, but most importantly they serve as an essential evidence of the crimes committed against civilization and humanity by the Ottoman Empire. These photos with their exceptional stories give the audience an opportunity to get a deep insight of the tragedy of the Armenian people. The photos not only come to prove the genocidal policy performed by Turkish Government, but also raise awareness, call for action in order to prevent similar tragedies in the future. The recorded terrible scenes from history speak with us through photographs in the language of facts - facts of struggle.

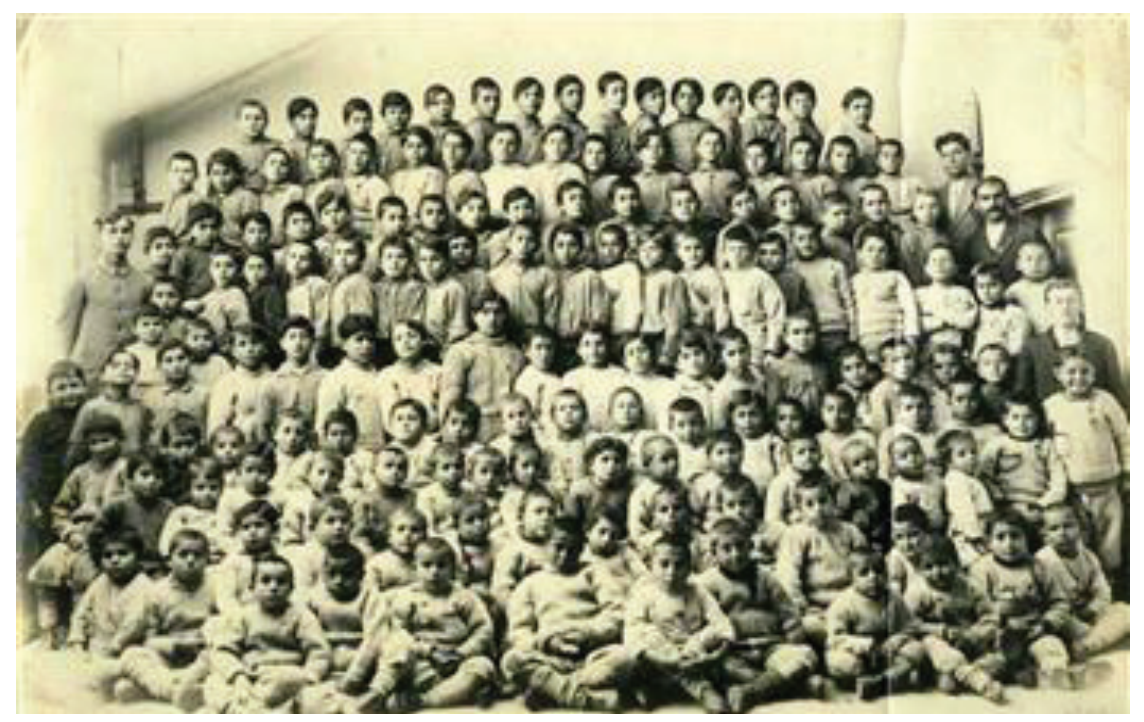

In an interview with Todays Zaman, Marsoobian talked about the major goal of his exhibition: "The exhibition changes a little, depending on the location. But what I would like to do is to expose Turkish citizens, whether they are of Armenian background or not, to the cultural wealth of these lands from which Armenians were removed in 1915 and where, in years after, they were silenced and repressed" (Marsoobian, 2014).
It is important to note how working with these materials and realizing this memorialization project coincided and matched with professor's work in philosophy, particularly in the fields of moral theory and ethics. Armenian-American professor sees photography as an art form, accordingly sharing them as sharing the art. He is sharing memories and history through the art of photography. These materials are irreplaceable source of education that leaves room for questions and clarifications. 


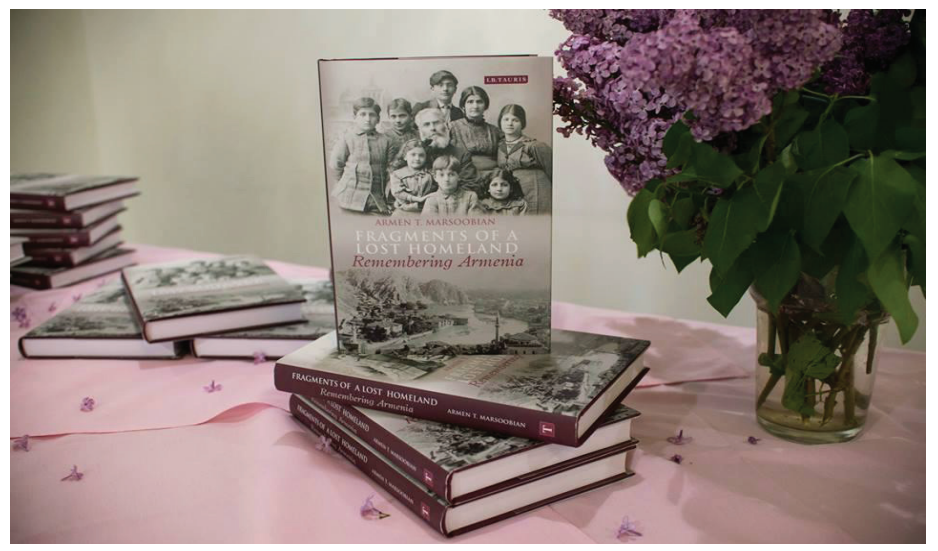

The Armenian Genocide had critical impact on people's lives, besides all of the innocent victims people were displaced from their homeland left without anything and yet only few people could survive. Armen Marsoobian's book “Fragments of a Lost Homeland: Remembering Armenia" is collective work of history that Dildilian family preserved and transferred throughout time to next generations. The Dildilians chose to speak up about their experience and history of the Armenian people. Professor Marsoobian used all of the saved resources: video and audio recordings, memoirs, diaries, letters and, of course, photographs and drawings to represent Armenian and Ottoman history from the late nineteenth century to the 1920s.

Professor Marsoobian's exhibitions, lectures and books on the Armenian Genocide present different facts and angles of the history to the world. His work and devotion are great sources of appreciation. "The unexamined life is not worth living" (Socrates). The unsolved wounds that come from history need to be examined the most.

\section{Profile:}

Armen T. Marsoobian is a professor of philosophy and chairman of the Philosophy Department at Southern Connecticut State University. He holds a Ph.D. in philosophy from the State University of New York at Stony Brook. His articles on Dewey, Peirce, Buchler, Emerson, pragmatism, aesthetics, and genocide studies have appeared in a variety of journals and anthologies. He has co-edited two books in systematic metaphysics, the first an expanded and revised edition of Justus Buchler's Metaphysics of Natural Complexes, the second, an anthology of essays on philosophical naturalism entitled Nature's Perspectives: Prospects for Ordinal Metaphysics. He published an anthology of essays on classic American philosophy, entitled The Blackwell Guide to American Philosophy. He is editor-inchief of the Wiley-Blackwell philosophy journal Metaphilosophy and is also general series editor for monographs in contemporary philosophy entitled, Metaphilosophy Series in Philosophy, published by Wiley-Blackwell Publishers. His article, "Acknowledging Intergenerational Moral Responsibility in the Aftermath of Genocide," appeared in Genocide Studies and Prevention (2009). His recent essay, "Rescue in Marsovan: The Untold Story Behind a Photograph," won the Hrant Dink Prize for Historical Research in 2011.

$\mathrm{He}$ is a frequent presenter at conferences and seminars on topics related to his work on genocide, including reparations, reconciliation and memorialization. He has lectured on these topics in Armenia, Europe, South America and the United States.

\section{REFERENCES}

Photo 1:

Dr. Armen Marsoobian to Speak at Fresno State University. (2015, April 31). Retrieved January 5, 2016, from Asbarez: 
http://asbarez.com/139309/dr-armen-

marsoobian-to-speak-at-fresno-state-

university/

Photo 2:

Exhibition reflects dark period of Anatolian history.

(2013, April 29). Retrieved January 4, 2016, from Hurriyet Daily News:

http://www.hurriyetdailynews.com/Defau

It.aspx?pagelD $=238 \& n \mid D=45807 \&$ NewsCat

ID=385

Photo 3:

Professor Armen Marsoobian Tells the Story of His "Islamized" Armenian Family during the Genocide. (2015, April 28). Retrieved January 4, 2016, from AUA Newsroom: http://newsroom.aua.am/2015/04/28/pro fessor-armen-marsoobian-tells-the-storyof-his-islamized-armenian-family-duringthe-genocide/

Profile:

Department Chair: Armen Marsoobian. (n.d.). Retrieved January 4, 2016, from Southern Connecticut State University: http://www.southernct.edu/academics/sc hools/arts/departments/philosophy/facult yandstaff/department-chair.html

Marsoobian, A. (2014, June 28). ArmenianAmerican professor hopes to start dialogue with exhibitions. (T. Zaman, Interviewer) 